\title{
PENGARUH PENGGUNAAN FACEBOOK BAGI KEHIDUPAN ROHANI MAHASISWA STKIP WIDYA YUWANA
}

\author{
Anastasia Dwilestari, Agustinus Wisnu Dewantara*) \\ STKIP Widya Yuwana \\ anastasiad835@gmail.com \\ *)penulis korespondensi, dewantaracm@widyayuwana.ac.id
}

\begin{abstract}
The church is always determined to serve the people of its time, and also to keep abreast of the times with its ways. The development of the technological age that is seen, one of them is the internet that provides various kinds of social networks. Facebook is one of the social networks used in everyday life and influences the user. Based on the background above, the researcher can formulate a number of problem formulations as follows: What is meant by Facebook? What is meant by spiritual life? What is the influence using of Facebook on the spiritual life of students in STKIP Widya Yuwana Madiun? This study aims to describe the meaning of Facebook; describe the meaning of spiritual life, describe the influence using of Facebook on spiritual life of students in STKIP Widya Yuwana. This study used a qualitative method by collecting data through interviews with 8 respondents. Qualitative research is an open interview as an effort to examine and understand the attitudes, views, feelings and behavior of individuals or groups of people on a problem. Qualitative methods are as a form of research that is more focused on efforts to see, understand attitudes, feelings, views and behaviors both individually and in groups regarding an event.
\end{abstract}

Keywords: facebook, spiritual life, students of STKIP Widya Yuwana.

\section{PENDAHULUAN}

Gereja selalu bertekad untuk melayani umat pada zamannya, dan turut mengikuti perkembangan zaman dengan caranya. Pembinaan kehidupan rohani umat, merupakan tugas Gereja sebagai Ibu dan Guru. Gereja mengikuti perkembangan ilmu pendidikan dan teknologi. Perkembangan teknologi yang dimaksud adalah internet. Kemajuan ilmu pengetahuan dan teknologi internet yang dicapai oleh manusia melahirkan sebuah tatanan dunia baru yakni globalisasi. Globalisasi menciptakan sikap ketergantungan yang luar biasa antara media dan manusia (Komisi Kateketik KWI 2016: V).

Perkembangan ilmu dan teknologi internet harus disyukuri sebagai kemajuan peradaban manusia. Kehidupan manusia menjadi semakin mudah, salah satunya dalam hal komunikasi menggunakan internet. Perkembangan teknologi internet membutuhkan sikap bijak, agar menjadi tepat guna dan bukan salah guna. Kemajuan ilmu teknologi komunikasi menggunakan internet sebagai media pengembangan harus diarahkan oleh 
manusia, jangan manusia yang diarahkan oleh teknologi komunikasi internet (Komisi Kateketik KWI 2016: V).

Teknologi internet merupakan salah satu hasil dari perkembangan zaman yang selalu dimanfaatkan oleh manusia-manusia modern. Teknologi internet yang banyak digunakan adalah facebook. Dengan menggunakan facebook, komunikasi secara global bisa dilakukan dengan sangat cepat. Segala macam informasi juga dapat diperoleh melalui media facebook, entah itu informasi lokal maupun internasional. Perkembangan facebook sangat berpengaruh besar terhadap kehidupan manusia dewasa ini. Relasi antar manusia menjadi lebih luas dengan adanya media facebook (Arief, 2011: 156).

Facebook sebagai media yang memiliki kelebihan dan kekurangan juga digunakan oleh mahasiswa. Mahasiswa yang menggunakan facebook salah satunya adalah mahasiswa STKIP Widya Yuwana. Penggunaan facebook memiliki kelebihan namun pada kenyataannya penggunaan facebook juga memiliki kekurangan. Maka munculah pertanyaan apakah penggunaan facebook berpengaruh bagi kehidupan rohani mahasiswa STKIP Widya Yuwana. Berdasarkan uraian tersebut di atas, muncul beberapa pertanyaan tentang apa arti facebook? Apa arti kehidupan rohani? Apa pengaruh penggunaan facebook bagi kehidupan rohani mahasiswa STKIP Widya Yuwana?

\section{PENGARUH PENGGUNAAN FACEBOOK BAGI KEHIDUPAN ROHANI}

\subsection{Pengertian Facebook}

Facebook menurut wikipedia berbahasa Indonesia adalah sebuah layanan jejaring sosial dan situs web yang diluncurkan pada 4 Februari 2004. Facebook adalah situs jejaring sosial (social networking) atau disebut juga layanan jaringan sosial secara online, yang memungkinkan penggunanya saling berinteraksi dan berbagi informasi di seluruh dunia (Arifin, 2009: 30). Media komunikasi merupakan salah satu yang termasuk dalam jaringan internet adalah jejaring sosial. Jejaring sosial adalah sutau struktur sosial yang dibentuk dari simpul-simpul yang diikat dengan satu tipe relasi spesifik atau lebih, seperti nilai, visi, ide, teman, keturunan dan sebagainya (Kindarto, 2010: 1).

Facebook merupakan salah satu layanan jejaring sosial internet yang gratis dimana manusia dapat membentuk jaringan dengan mengundang teman. Melalui jaringan yang dibentuk, manusia dapat memperhatikan aktivitas sesama. Mengikuti permainan atau join game yang direkomendasikan, menambah teman atau jaringan kita berdasarkan organisasi sekolah, daerah domisili, dan dapat dikatakan fasilitas untuk berteman serta membina kehidupan sosial. Facebook pun memiliki fitur dan konten yang sangat variatif dan inovatif. Hal ini pula yang menjadikan facebook banyak diminati orang sehingga menjadi media jejaring sosial.

Jejaring sosial adalah struktur sosial yang terdiri dari elemen-elemen individual atau organisasi. Jejaring ini menunjukkan, manusia berhubungan karena kesamaan sosialitas, mulai dari mereka yang dikenal sehari-hari sampai dengan keluarga. Jejaring sosial telah menjadi gaya hidup bagi sebagian besar masyarakat Indonesia dan telah menguasai kehidupan para pengguna internet. Facebook merupakan salah satu situs jejaring sosial yang terkenal saat ini, karena facebook membantu penggunanya untuk bisa saling berinteraksi, saling berkirim pesan, bertemu dan memelihara persahabatan dengan teman lama, mencari teman baru, chatting, bermain bersama, berbagi file dan foto, 
mencari partner bisnis, bermain game online bersama teman, dan sebagainya (Pradani, 2014: 40).

Facebook adalah website jaringan sosial dimana para pengguna dapat bergabung dengan komunitas seperti kota, kerja, sekolah, dan daerah untuk melakukan hubungan dan berinteraksi dengan orang lain. Seseorang yang menggunakan facebook juga dapat menambahkan teman-teman mereka, mengirim pesan, dan memperbaharui profil pribadi agar orang lain dapat melihat tentang dirinya (Saputra, 2004: 25).

Facebook adalah sebuah situs website jejaring sosial populer yang diluncurkan pada 4 Februari 2004 dan didirikan oleh Mark Zuckerberg, seorang mahasiswa Harvard kelahiran 14 Mei 1984 (Arifin, 2009: 40). Definisi ini dapat menyimpulkan bahwa facebook adalah suatu situs jejaring sosial atau networking yang memungkinkan penggunanya dapat berinteraksi sosial diseluruh dunia.

Facebook adalah website jaringan sosial dimana para pengguna dapat bergabung dalam komunitas seperti kota, kerja, kampus, dan daerah untuk melakukan koneksi dan berinteraksi dengan orang lain. Facebook dibandingkan dengan website yang lain, lebih memberikan fasilitas yang lengkap seperti halaman profil, album foto dan video, obrolan (chat), catatan, aplikasi halaman, aplikasi bisnis, permainan dan jaringan (Arifin, 2009: 9).

\subsubsection{Sejarah Facebook}

Asal mula facebook berawal ketika Mark Zuckerberg membuat sebuah situs kontak jodoh untuk rekan-rekan kampusnya. Terinspirasi dari situs Hot or Not, Zuckerberg memberi nama situsnya Facemash.com. Metode situs itu yaitu menampilkan dua foto pasangan (pria dan wanita), di mana kedua pasangan ini akan dipilih oleh para anggota situs mana pasangan yang paling "hot”. Mark Zuckerberg berupaya dengan segala cara mencari foto-foto rekannya dengan cara “door-to-door” untuk meminta foto.

Mark Zuckerberg membobol akses jaringan komputer kampusnya untuk mendapatkan foto-foto tambahan. Aksi pembobolan jaringan komputer ini diketahui oleh pihak kampus dan facemash.com diblokir. Mark Zuckerberg mendapat ancaman atas tindakannya akan dipecat dari kampus, Mark Zuckerberg membela diri.

Pengguna facebook pada awalnya dibatasi untuk siswa dari Harvard College. Dua bulan kedepan, keanggotaan diperluas ke sekolah lain di wilayah Boston (Boston College, Boston University, MIT, Tufts), Rochester, Stanford, NYU, Northwestern, semua sekolah yang termasuk dalam lvy League, dan perguruan tinggi lainnya ditambahkan berturutturut dalam kurun waktu satu tahun setelah peluncurannya. Pengguna facebook yang memiliki e-mail suatu universitas (seperti: .edu, .ac, .uk, dll) dari seluruh dunia dapat juga bergabung dengan situs ini.

\subsubsection{Dampak Positif dan Negatif Facebook}

Dampak positif dari perkembangan internet khususnya facebook terhadap kehidupan manusia adalah mempermudah dalam mencari informasi dan menemukan teman baru walaupun berbeda tempat tinggal. Perkembangan media komunikasi facebook dapat mempermudah untuk mendapatkan informasi dari seluruh dunia. Mahasiswa dapat 
dengan mudah mencari teman dan mendapatkan informasi tentang update status oranglain yang sudah menjadi temannya di facebook.

Facebook sebagai jaringan sosial mempunyai keunggulan yakni kemudahan penggunaan dan kenyamanannya. Seseorang akan mudah untuk mencari teman hanya dari fungsi "search" yang memungkinkan untuk menemukan teman lama secara mudah dan juga dapat menemukan teman lama yang sudah lama tidak dijumpai. Teman lama yang tidak dijumpai karena letak geografis bisa ditemukan melalui facebook (Olson, 2008: 4).

Dampak positif facebook yang dirasakan mahasiswa adalah sebagai sumber informasi. Facebook menjadi sumber informasi untuk kampus tentang keperluan administrasi maupun tentang lowongan pekerjaan. Facebook sebagai sumber informasi dan juga sebagai wadah memperoleh banyak teman. Facebook mempertemukan seseorang dari kampus yang sama dan juga dari luar kampus, dari satu daerah dan luar daerah, serta dari dalam negeri maupun luar negeri. Facebook mempertemukan manusia dari segala penjuru dunia.

Fasilitas yang ditawarkan internet apabila tidak disikapi dengan bijak bisa menyebabkan penggunanya lupa waktu. Pengguna sudah kecanduan dengan facebook, hal ini bisa membuat pengguna lupa akan segalanya. Kegiatan lain dilupakan, termasuk waktu berdoa untuk memuliakan Allah. Fasilitas facebook yang bisa merusak kehidupan rohani adalah berita hoax yang membuat penasaran, informasi tentang agama dan politik yang berunsur sara.

Salah satu kelemahan facebook adalah tidak ada filter atau penyaring isi informasi. Informasi yang tidak baik bisa berpengaruh buruk terhadap penggunanya. Tantangan yang harus diwaspadai dalam menggunakan media komunikasi salah satunya adalah facebook. Interaksi dan dialog dua arah di facebook dapat berpotensi menimbulkan kebingungan karena pihak yang bertanya mempunyai kesempatan untuk menyampaikan pandangan secara bebas sehingga semua pihak terlibat dalam interaksi lewat facebook.

Dunia media terkadang sangat fanatik terhadap ajaran iman dan moral Kristiani. Fanatik disebabkan karena adanya pandangan umum yang menganggap tidak ada kebenaran mutlak. Pendapat adalah benar karena pandangan umum. Situs di internet yang ditujukan untuk menyerang kelompok-kelompok agama ataupun budaya tertentu, tidak terkecuali yang menyerang Gereja Katolik dapat berpengaruh negatif bagi kehidupan iman. Situs yang menamakan dirinya Katolik tetapi tidak menyampaikan informasi yang sesuai dengan otentisitas Gereja Katolik. Situs ini mungkin didirikan dengan maksud baik namun pandangan yang disampaikan dalam situs itu sangat pribadi dan eksentrik atau berbeda dengan ajaran resmi Gereja Katolik (Patriadi, 2015: 18).

Arus informasi yang bebas di facebook dapat menimbulkan dampak negatif bagi penggunanya. Informasi berbau pornografi, kekejaman dan hal-hal yang tidak sesuai dengan budaya setempat akan sangat mudah ditemui. Informasi ini akan menimbulkan rasa ketidaknyamanan sebagai pengikut Kristus yang harus melakukan tindakan baik dalam mendukung hidup rohaninya. 


\subsubsection{Manfaat Facebook}

Facebook merupakan situs jejaring sosial yang mendunia. Manfaat facebook adalah sebagai media untuk promosi, untuk saling mengenal, dan tempat menemukan informasi. Facebook digunakan sebagai media untuk melakukan promosi terhadap kampus supaya lebih dikenal banyak orang. Facebook sebagai media untuk saling mengenal satu dan yang lain, misal teman satu kampus, teman beda kampus, teman beda budaya, teman beda tempat tinggal dan teman beda suku serta budaya. Banyak teman dikenal melalui facebook dan dapat membantu seseorang memiliki banyak teman diseluruh dunia. Berteman dengan banyak orang merupakan kesenangan tersendiri bagi seseorang. Teman yang banyak membantu seseorang mendapatkan banyak informasi dan pengalaman (Cangara, 1998: 30).

Facebook digunakan sebagai hiburan dalam waktu luang. Facebook sebagai tempat hiburan dapat membantu mahasiswa berpikir luas tentang dunia karena setiap hari mahasiswa selalu belajar dan belajar, maka dengan facebook mahasiswa menjadi terhibur. Facebook bermanfaat bagi mahasiswa sebagai wadah untuk mengeluarkan banyak keluh kesah tentang pergumulan hidup sehar-hari (Kindarto, 2010: 10).

Facebook digunakan untuk mengundang banyak orang sebagai teman. Setelah lama berteman bisa saja menjadi sahabat dan bahkan menjadi pacar. Facebook juga membantu seseorang untuk menemukan pasangan hidupnya. Facebook digunakan sebagai tempat untuk melihat banyak berita tentang realita hidup seseorang. Realita hidup yang baik maupun yang kurang baik dan dapat dijadikan sebagai pengalaman baru untuk hidupnya. Facebook sebagai media berkomunikasi (Kindarto, 2010: 25).

\subsection{Kehidupan Rohani}

\subsubsection{Pengertian Kehidupan Rohani}

Kehidupan berasal dari kata "hidup", sedangkan definisi hidup adalah "masih terus ada bergerak, dan bekerja sebagaimana mestinya" (Kamus Umum Bahasa Indonesia, WJS. Poerwadarminta, Balai Pustaka, Jakarta, 1976, hal. 335). Kebanyakan orang mengatakan bahwa hidup adalah sesuatu yang sangat berharga, anugerah Allah yang tidak ternilai, oleh sebab itu hidup harus dihormati dan dijunjung tinggi. Kata rohani berasal dari kata Ibrani “ruah" yang berarti nafas (Heuken, 2005: 120). Hidup yang ada di dalam tubuh manusia sering dihubungkan dengan adanya nafas sehingga manusia sebagai mahluk rohani berarti manusia sanggup berhubungan dengan Sang Sumber hidupnya. Kehidupan rohani memiliki makna lebih, jika dipusatkan pada kesanggupan untuk berhubungan dengan Tuhan dan menyadari kehadiran Sang Ilahi dalam hidupnya. Manusia dipanggil untuk mengenal Dia yang hadir dalam hatinya.

Hidup rohani juga menyangkut "roh” (spirit). Roh mengacu pada keseluruhan diri sejati. Siapa diri kita tercermin dalam sikap terhadap Tuhan. Aspek rohani mencakup segala sesuatu yang bersifat "immaterial" dan tidak terlihat secara fisik, karena itu kehidupan rohani mencakup sikap hati, jiwa atau roh secara keseluruhan terhadap Tuhan (Hidya Tjahya, 2011: 60).

Alkitab menyebutkan suatu unsur yang mutlak perlu bagi kerohanian manusia. Santo Paulus dalam suratnya kepada umat di Korintus mengemukakan bahwa manusia rohani digambarkan sebagai orang yang menerima roh yang berasal dari Allah. Roh itu 
adalah tenaga aktif Allah, dan bekerjanya roh tersebut merupakan syarat mutlak untuk mengetahui hal-hal rohani. Seseorang bisa menguji dan memahami segala sesuatu dari sudut pandang rohani. Orang yang tidak memiliki Roh Allah disebut manusia jasmani, yang menganggap hal-hal rohani sebagai kebodohan (1 Kor 2:12-15).

Kerohanian yang sejati tidak bisa dikembangkan melalui hikmat manusia semata, melainkan harus dimiliki dengan kesanggupan untuk bertindak dan berpikir seperti Allah karena diciptakan menurut gambar-Nya. Kesadaran akan kesanggupan pribadi atau prestasi pribadi memerlukan Roh Kudus dari Allah. Orang yang menolak kehadiran Roh Allah, tetapi memilih untuk mengejar keinginannya sendiri, digambarkan sebagai orang yang tidak rohani (Heuken, 2005: 122). Seseorang yang mengejar keinginannya untuk bermain facebook daripada menjalankan hidup rohaninya berarti orang yang tidak menerima Roh.

Roh mendorong setiap orang beriman untuk semakin bertumbuh dan berkembang menjadi pribadi yang semakin rohani dalam segala keadaan. Kehidupan manusia adalah proses riwayat hidup masing-masing dan berlangsung terus sampai manusia meninggalkan dunia. Rahmat panggilan, cita-cita rohani dan berkat-berkat kodrat yang merupakan dasar kemanusiaan (Mardiatmadja, 1982: 50).

Kerohanian adalah sesuatu yang menunjukkan isi dari pernyataan pengalaman hidup manusia dalam menghayati hubungannya dengan Allah, sesama manusia maupun dengan alam semesta, penghayatan ini tidak lain sebagai usaha menuju kepenuhan hidup (Darminta, 1985: 16). Pengalaman yang telah dialami manusia, baik atau buruk, suka atau tidak, semuanya dimaknai sebagai suatu proses atau sebagai bentuk refleksi manusia itu sendiri untuk semakin mendekatkan diri kepada Allah.

Manusia berusaha mencukupi kebutuhan hidupnya, baik jasmani maupun rohani. Kehidupan rohani berhubungan erat dengan roh. Dalam kamus disebutkan bahwa rohani adalah "Roh", berupa roh yang bertalian atau berkenaan dengan roh, yang tidak berbadan jasmani, yang berbekal budi dan berperasaan” (Poerwadarminta, 1976: 830).

Menurut ajaran Gereja, pengertian "Rohani” adalah yang berhubungan dengan roh khususnya dengan Roh Kudus dan kegiatan serta hasil kegiatan itu sering diartikan sebagai yang tidak material (jiwa rohani) sebagai yang berhubungan dengan agama (bacaan rohani) dan kehidupan rohani. Kehidupan rohani dilaksnakaan oleh orang yang mengarahkan pikiran, perbuatan, dan seluruh hidupnya kepada Allah. Kehidupann itu menjadi nyata dalam semangat iman yang kuat, cinta kasih dan harapan berkembang dan bergiat dalam doa keutamaan-keutamaan Kristiani (Agustinus, 2015: 53).

Manusia zaman sekarang ada yang begitu mencintai imannya akan Yesus dan sebaliknya ada yang menolak dan tampak jauh dari Tuhan, namun demikian Roh Kudus tetap bekerja dalam diri manusia. Umat Kristiani sangat memerlukan kasih Tuhan dalam kehidupannya sehari-hari. Kehidupan rohani umat Kristiani harus memiliki relasi yang dekat dengan Tuhan. Manusia berkehendak untuk sampai kepada Allah melalui Yesus Kristus maka niatnya harus dilaksanakan dengan seluruh jiwa raganya, dalam setiap tindakan kehidupan sehari-hari, dalam perjalanannya di tengah sesama dan di tengah lingkungan keluarganya (Heuken, 2005: 125). 


\subsubsection{Bentuk-Bentuk Kehidupan Rohani}

Hidup rohani yang semakin matang dan mendalam dapat dicapai dengan mempererat hubungannya dengan Tuhan, antara lain dengan mendengarkan sabda-Nya dalam Injil melalui hatinya, semakin menghidupkan dan meningkatkan cara berdoa. Berdoa merupakan kegiatan manusia yang paling mulia. Doa dalam segi kehidupan dan iman berarti seseorang menyatu, lalu dihantarkan kepada Tuhan. Panggilan pribadi didengar dan dipertajam dalam doa, karena Tuhan memanggil kita sebagai anak-Nya yang disayangi-Nya. Tugas sebagai anak ialah menyapa Tuhan dengan berterimakasih, memuji dan meminta, namun terutama dengan mendengarkan-Nya dalam hati bukan dengan bermain Facebook. Tuhan sendirilah yang menuntun kita dalam dan melalui berbagai peristiwa hidup kita (Budyapranata, 1981: 30).

Kehidupan Rohani dapat dirumuskan sebagai usaha masing-masing pribadi untuk mengubah diri atau mentransformasikan hidup dalam Kristus. Seperti yang dituliskan dalam Surat Paulus kepada jemaat di Galatia "namun aku hidup, tetapi bukan lagi aku sendiri yang hidup, melainkan Kristus yang hidup di dalam aku. Dan hidupku yang kuhidupi sekarang di dalam daging, adalah hidup oleh iman dalam Anak Allah yang telah mengasihi aku dan menyerahkan diri-Nya untuk aku (Gal 2:20)”. Kehidupan rohani dapat dicapai melalui kemampuan untuk membatinkan atau menginternalisasikan hidup Kristus. Kehidupan rohani yang dimiliki oleh manusia merupakan kewajiban sebagai seorang yang beriman dan percaya kepada Allah. kehidupan itu menjadi nyata dalam semangat iman yang kuat, cinta kasih dan harapan berkembang dan bergiat dalam doa keutamaankeutamaan Kristiani (Agustinus, 2015: 53).

\subsubsection{Doa Pribadi dan Doa Bersama}

Cara hidup jemaat perdana dalam hidup doa mau menunjukkan kepada kita bahwa, umat Kristiani senantiasa mengandalkan Allah dalam segala hal. Injil Yoh 15:7-8 mengatakan "jikalau kamu tinggal didalam Aku dan Firman-Ku tinggal didalam kamu, mintalah apa saja yang kamu kehendaki. Dalam hal ini Bapa-Ku dipermuliakan, yaitu jika kamu berbuah banyak dan dengan demikian kamu adalah murid-Ku”. Allah sendiri mengajak kita untuk tetap mendengarkan Firman-Nya dan tinggal didalam kita agar kita tidak jatuh kedalam cengkraman dosa (bdk. Yoh 8:31-32). Kemudian kita diajak untuk meminta apa saja melalui ungkapan doa kita dan Allah sendiri berjanji akan memberikan kepada kita dan sesuai yang kita kehendaki (bdk. Mat 7-11). Doa merupakan suatu dialog yang terjadi antara manusia dan Allah. Doa menjadi kesempatan bagi manusia untuk berbicara dengan Allah sesuai dengan apa yang dipikirkan dan dirasakannya (Euvemia, 2018: 27).

\subsubsection{Mengikuti Perayaan Ekaristi}

Persekutuan jemaat perdana dalam kebersamaan memecahkan roti atau perayaan Ekaristi melambangkan tanda kehadiran Tuhan sebagai sumber segala kebaikan yang memberi kekuatan dan kehidupan bagi manusia. Tuhan ibarat sumber air yang selalu mengalir untuk memberi kehidupan bagi semua mahluk dan menampakkan cinta-Nya yang tidak pernah berhenti. Ini merupakan sebuah kesetiaan Allah dalam kasih-Nya yang selalu terpancar dalam diri Yesus. Ekaristi memiliki arti ucapan syukur atas karya 
penebusan dan penyelamatan sebagaimana berpuncak dalam peristiwa sengsara, wafat dan kebangkitan Kristus, maka dari itu Gereja mengenang dan menghadirkan kembali misteri penebusan Kristus (Juna, 2018: 135).

\subsubsection{Membaca dan Merenungkan Kitab Suci}

Kitab Suci adalah "Wahyu Allah”. Wahyu atau penyataan Allah tentang diri-Nya ini tidak terlepas dari kenyataan bahwa manusia diciptakan menurut gambar dan rupa Allah (Kej 1:26). Manusia adalah mahluk rohani yang diciptakan menurut gambaran Allah, yang dilengkapi oleh akal budi dan kehendak bebas, sehingga manusia dapat mengetahui, memilih dan mengasihi.

Umat Kristiani mempunyai kebiasaan untuk membaca dan merenungkan Kitab Suci. Kitab Suci yang sudah dibaca dan direnungkan isinya menjadikan umat Kristiani mengenal Allah yang menyelamatkan manusia dalam sejarah keselamatan yang berpuncak dalam diri Yesus Kristus. Kitab Suci yang dibaca, direnungkan dan didengarkan akan mengarahkan hati kepada Allah yang hadir melalui sabda-Nya, sehingga umat Kristiani dapat menimba inspirasi hidup iman melalui teladan hidup Yesus dan tokoh-tokoh iman dalam Kitab Suci (KWI, 2012: 35).

\subsubsection{Ikut Aktif dalam Kelompok Pembinaan Iman}

Umat Kristiani dapat memberikan pendidikan iman dan menumbuhkan sikap hidup menggereja dalam dirinya dengan terlibat aktif dalam kegiatan menggereja baik di lingkungan, wilayah, maupun paroki. Iman akan tumbuh dan berkembang dengan baik melalui pembinaan dan umat Kristiani dapat menghayati kebersamaan hidup sebagai anggota Gereja (KWI, 2012: 35).

Umat Kristiani dapat mengikuti Komunitas Basis Gerejawi (KBG) untuk menumbuhkan iman dalam kebersamaan. Komunitas Basis Gerejawi dilaksanakan untuk membina iman umat Allah. Seseorang yang ikut dalam Komunitas Basis Gerejawi diterima secara eksistensial dan dapat berkembang, tidak eksklusif melainkan menyatu, terbuka dan terlibat dengan komunitas-komunitas lain baik dalam kehidupan Gereja maupun masyarakat, memiliki visi, misi dan spiritualitas yang mendorong terlaksananya pola hidup baru berorientasi pada Kerajaan Allah, membuat orang betah dan ketagihan dan adanya timbal balik antara pribadi dan komunitas, yaitu saling mengembangkan (Dokumen PKKI-VII, 2006: 121).

\subsubsection{Ikut Ambil Bagian dalam Rekoleksi, Retret, Ziarah}

Rekoleksi merupakan salah satu proses yang digunakan untuk mengetahui atau menggali masa lalu dari seseorang dengan cara memanggil kembali memori dari masa lalu seseorang terhadap suatu kejadian tertentu pada masa hidupnya. Proses ini dilakukan untuk pemulihan spiritualitas dari seseorang maupun untuk fisioterapi untuk menghilangkan trauma terhadap suatu kejadian tertentu.

Tujuan rekoleksi adalah mengembalikan penghargaan terhadap hal-hal yang hakiki. Rekoleksi memberikan kesempatan baik untuk menyiapkan rencana masa depan dan meneruskan perjalanan hidup dalam keadaan lebih segar secara rohani. Dengan kata 
lain, rekoleksi menjadi kesempatan untuk mengatur kembali yang kurang diperhatikan dalam kesibukan sehari-hari (Agustinus, 2015: 33).

Retret berasal dari kata dalam bahasa Inggris “retreat” yang berarti menarik diri atau mengasingkan diri. Dari arti hurufiah itu, diambil pengertian yang dipakai secara umum yaitu menarik diri atau mengasingkan diri dari keramaian atau dari kesibukan rutin dan pergi ke suatu tempat yang tersendiri dan sepi selama waktu tertentu untuk beristirahat atau untuk memusatkan perhatian pada hal-hal atau tugas pelayanan khusus. Ziarah adalah salah satu praktek sebagian besar umat beragama yang memiliki makna moral yang penting. Terkadang ziarah dilakukan ke suatu tempat yang suci dan penting bagi keyakinan dan iman yang bersangkutan. Tujuan ziarah adalah mengingat kembali, meneguhkan iman atau menyucikan diri (Agustinus, 2015: 36).

\subsubsection{Refleksi Harian}

Refleksi harian merupakan hal yang paling penting dalam hidup manusia, karena dengan refleksi manusia dapat menemukan siapa diri yang sesungguhnya dengan segala situasi hidup yang dialami dan dirasakan, sehingga dapat memaknai hidup ini begitu berarti. Umat Kristiani mampu merefleksikan setiap pengalaman yang dialami dalam hidup sehari-hari sehingga mampu menerima segala kekurangan dan kelebihan setiap orang agar hidup semakin sempurna dimana ada muncul cinta kasih (KWI, 2012: 38).

\subsubsection{Meditasi}

Meditasi adalah praktek relaksasi yang melibatkan pelepasan pikiran dari semua hal yang menarik, membebani, maupun mencemaskan dalam hidup manusia sehari-hari. Tujuan meditasi adalah mengenali jati diri dan mencapai kebahagiaan batin (Agustinus, 2015: 24). Maksudnya adalah bahwa seseorang mampu untuk menyediakan waktu dan tempat khusus yang memungkinkan untuk menumbuhkan rasa cinta kepada keheningan dimana seorang merasa dekat dengan Yesus, dipenuhi dengan Roh-Nya, serta berada dalam pelukan kasih Allah sendiri.

\subsubsection{Lectio Divina}

Konsili Vatikan II dalam Dei Verbum art. 25, menyatakan bahwa sangat dianjurkan untuk membaca Kitab Suci serta senantiasa untuk berpegang pada Kitab Suci. Oleh sebab itu semua rohaniwan, terutama para imam Kristus serta lain-lainnya, yang sebagai diakon atau katekis secara sah menunaikan pelayanan sabda, perlu berpegang teguh kepada Alkitab dengan membacanya dengan asyik dan mempelajarinya dengan seksama.

\subsubsection{Ibadat Pagi}

Konsili Vatikan II melalui Dekrit tentang Liturgi Suci menganjurkan agar doa ofisi atau ibadat harian didoakan oleh para imam maupun anggota-anggota Gereja yang lainnya dan dengan demikian semua yang mendoakannya tergabung dalam kesatuan doa Gereja di seluruh dunia dalam kesatuan dengan Kristus sang Kepala. Dalam hal ini, sangatlah besar manfaat dari ibadat pagi, sebagai usaha mendekatkan diri kepada Kristus lewat bacaan-bacaan Injil yang didengar pada hari itu. Disamping itu juga, hendaknya apa 
yang telah didengar serta direnungkan, dapat diterapkan secara nyata dalam kehidupan sehari-hari supaya kasih Kristus benar-benar nampak.

\subsubsection{Tujuan Hidup Rohani}

\subsubsection{Meningkatkan Relasi dengan Tuhan}

Hidup merupakan anugerah indah dari Tuhan, yang harus selalu terasa indah bila dihayati sesuai dengan tujuan yang dikehendaki oleh Tuhan. Manusia harus menyadari bahwa Tuhan senantiasa mengasihi dan menyayangi semua milik-Nya, termasuk manusia tanpa batas. Tuhan adalah kasih dan kasih-Nya yang telah diterima dengan cuma-cuma hendak dibagikan kepada semua mahluk ciptaan sehingga merekapun mengalami kasih Tuhan. Manusia perlu belajar untuk lebih percaya kepada Tuhan dan menjalin relasi yang dekat dengan Tuhan supaya manusia dapat bersatu erat dengan Tuhan dan kembali seutuhnya kepada Tuhan. Relasi dengan Tuhan berarti manusia harus melibatkan Allah dalam kehidupan sehari-hari. Berdoa kepada Allah, membaca Firman-Nya, dan merenungkan ayat-ayat Alkitab dalam upaya untuk mengenal Allah dengan lebih baik. Relasi antara manusia dengan Tuhan tidak sulit untuk dibangun karena merupakan kebutuhan hidup rohani yang harus terpenuhi. Manusia sebagai anak-anak Allah akan menerima Roh Kudus dan Roh Kudus akan bekerja di dalam manusia.

\subsubsection{Memupuk Relasi Kasih dengan Sesama Manusia}

Manusia adalah citra Allah. Manusia diciptakan oleh Allah menurut gambar dan rupa-Nya (Kej 1:26-27). Kasih menjadi dasar bagi Allah untuk menciptakan manusia dan selanjutnya menyelamatkan manusia. Kasih Allah menjadikan manusia dapat hidup. Manusia sebagai makhluk pribadi sekaligus makhluk sosial harus menjalin relasi yang penuh kasih dengan sesama. Manusia dapat hidup dengan aman, damai dan tenteram dengan sesamanya melalui relasi (Hidya Tjahya, 2011: 25). Manusia diciptakan dengan kodrat untuk dapat mengasihi Allah dan mengasihi sesama. Tuhan menciptakan manusia dengan kodrat untuk mengasihi karena tanpa kasih manusia tidak dapat mencapai surga. Rasul Yohanes mengatakan "barangsiapa tidak mengasihi, ia tetap di dalam maut" (1Yoh 3:14b). Ayat ini menyampaikan bahwa manusia dapat melihat bahwa untuk mendapatkan kesempatan, tidak ada cara lain, kecuali mengasihi. Pembinaan hidup rohani adalah usaha untuk hidup iman, sebab pada dasarnya hidup merupakan penyerahan diri penuh kepada Tuhan. Artinya, pembinaan hidup rohani sebagai alat atau jembatan bagi seseorang untuk berkembang dalam hidup bersama dengan Kristus, sebab pada dasarnya manusia itu sendiri sebagai ciptaan Tuhan. Pembinaan hidup rohani ini juga berusaha supaya sikap dan perilaku seseorang sehari-harinya sungguh mencerminkan nilai-nilai religius.

\subsubsection{Ruang Lingkup Kehidupan Rohani}

Kehidupan berasal dari kata hidup. Definisi kata "hidup" adalah "masih terus bergerak, dan bekerja sebagaimana mestinya” (Poerwadarminta, 1976: 355). Kehidupan rohani berhubungan dengan roh, dalam kamus disebutkan bahwa rohani adalah: Roh, berupa roh yang bertalian atau berkenaan dengan roh, yang tidak berbadan jasmani, yang berakal budi dan berperasaan”. 
Gereja mengatakan pengertian rohani adalah yang berhubungan dengan Roh Kudus dan kegiatan serta hasil kegiatannya sering diartikan sebagai yang tidak material (jiwa rohani) sebagai yang berhubungan dengan agama (bacaan rohani) dan kehidupan rohani (Poerwardarminta, 1976: 830). Kehidupan dilaksanakan oleh orang yang mengarahkan pikiran, perbuatan dan seluruh hidupnya kepada Allah. Kehidupan itu menjadi nyata dalam semangat iman yang kuat, cinta kasih dan harapan berkembang dan bergiat dalam doa keutamaan-keutamaan Kristiani (Heuken, 1975:118, 239).

\subsubsection{Aspek-Aspek Kehidupan Rohani}

Pembentukan kehidupan rohani adalah sebuah proses seumur hidup yang menolong seseorang untuk hidup menjadi seperti yang dikehendaki oleh pencipta. Kehidupan rohani berakar dalam hubungan antara manusia dengan Tuhan dan manusia dengan sesama. Pembentukan kehidupan rohani terjadi melalui kerja langsung Roh Kudus yang melahirkan dan menjadikan diri manusia serupa dengan gambaran Yesus Kristus. Roh Kudus berdiam dan mengisi (Efesus 5:18) untuk membimbing manusia kepada kebenaran sejati yang menghasilkan buah Roh di dalam kehidupan manusia dan menghadiahkan kepada manusia untuk melayani Gereja dan dunia ini.

Aspek kehidupan rohani adalah usaha untuk hidup iman, sebab pada dasarnya hidup merupakan penyerahan diri penuh kepada Tuhan. Aspek kerohanian merupakan langkah sebagai alat atau jembatan bagi seseorang untuk berkembang dalam hidup bersama dengan Kristus, sebab pada dasarnya manusia itu sendiri sebagai ciptaan Tuhan. Aspek kerohanian ini juga usaha supaya sikap dan perilaku seseorang sehari-harinya sungguh mencerminkan nilai-nilai religius (Agustinus, 2015: 21).

\subsection{Mahasiswa STKIP Widya Yuwana}

Mahasiswa STKIP Widya Yuwana menempuh perkuliahan sampai selesai untuk memperoleh gelar Strata Satu (S-1). Mahasiswa harus menjalani proses pembentukan kehidupan rohani. Kehidupan rohani disediakan oleh kampus selain daripada kesanggupan dari pribadi masing-masing mahasiswa untuk melakukannya. Kampus memfasilitasi dan mahasiswa hendaknya melakukan kewajiban berdoa sendiri di rumah, agar kehidupan rohani yang baik semakin terbentuk. Hidup kerohanian yang baik sangat berpengaruh bagi masa depan mahasiswa. Pendidikan kerohanian dari kampus yang didapatkan secara baik oleh mahasiswa akan membantu dalam proses tugas masa depan dan kewajiban sebagai katekis serta guru agama.

Mahasiswa STKIP Widya Yuwana dididik untuk menjadi seorang katekis dan guru agama. Sebelum terbentuk, mahasiswa STKIP Widya Yuwana harus memiliki pola kehidupan yang baik, khususnya dalam hal kerohanian. Hidup rohani yang baik harus dibiasakan untuk latihan kerohanian, contohnya dalam berdoa dan menekuni hidup berdasarkan Tuhan sebagai Sang pencipta.

\section{METODE PENELITIAN}

Penelitian ini bertujuan untuk mengetahui: 1) Pengertian facebook dan kehidupan rohani; 2) Apa pengaruh penggunaan facebook bagi kehidupan rohani mahasiswa STKIP Widya Yuwana. 
Untuk mencapai tujuan tersebut maka penelitian ini menggunakan metode kualitatif dengan pengumpulan data melalui wawancara pada 8 responden.

\section{HASIL PENELITIAN}

\subsection{Berapa Lama Penggunaan Facebook dalam Sehari}

Dari hasil penelitian di atas, para responden mengungkapkan tentang pengertian mereka berhubungan dengan berapa lama membuka facebook dalam setiap hari dan penggunaan facebook. Facebook digunakan oleh para responden hampir setiap hari. Penggunaan facebook setiap hari ada yang kurang dari 30 menit ada juga yang tepat 30 menit. Pengguna facebook menggunakannya ada yang kurang dari 3 kali dan ada yang sampai 5 kali. Penggunaan facebook setiap hari tidak hanya melihat postingan orang lain akan tetapi juga memposting foto, melihat status dan membuat status. Facebook setiap harinya tidak hanya dibuka, melainkan digunakan sesuai kemauan dan keinginan pengguna facebook.

Mahasiswa STKIP Widya Yuwana mengatakan facebook digunakan 4 kali selama 30 menit. Biasanya facebook digunakan untuk menonton film action, membaca berita dan chatting. Artinya facebook digunakan setiap hari selama 30 menit dan digunakan untuk menonton film action yang ada di facebook, membaca berita yang muncul di facebook dan juga chatting di facebook. Penggunaan facebook tidak hanya sekedar melihat postingan orang lain melainkan pengguna facebook sendiri juga menggunakan facebook untuk banyak hal. Mahasiswa STKIP Widya Yuwana mengatakan bahwa membuka facebook selama 30 menit. Penggunaan facebook selama 30 menit untuk upload foto, membuat status, melihat status/postingan orang lain. Para responden mengatakan bahwa penggunaan facebook hanya untuk melihat status orang lain, postingan foto, upload foto, update status dan chattingan. Facebook tidak digunakan untuk hal negatif seperti menonton film porno atau situs-situs yang berbau seksualitas.

Dari hasil penelitian di atas dapat diketahui bahwa para responden menggunakan facebook dalam sehari bisa 3-5 kali. Facebook digunakan untuk melihat status orang lain, membuat status, memposting foto, melihat berita, menonton film action dan chatting. Penggunaan facebook sesuai dengan keinginan masing-masing responden. Penggunaan facebook semua responden tidak sama karena keinginan tiap responden juga tidak sama. Facebook hanya sama-sama dibuka dan digunakan dalam setiap harinya sesuai keinginan masing-masing responden.

\subsection{Pengertian Facebook}

Berdasarkan hasil penelitian mengenai pengertian facebook, responden memiliki jawaban yang bervariasi. Beragamnya jawaban yang diberikan responden menunjukkan bahwa mereka memiliki pengertian yang berbeda antara satu sama lain meskipun ada beberapa jawaban yang sama. Pengertian facebook yang beragam yang disampaikan oleh para responden menunjukkan bahwa ada banyak sekali cara menyampaikan pengertian facebook dengan definisi masing-masing.

Hasil penelitian mengungkapkan berbagai pengertian tentang facebook. Facebook dianggap sebagai alat komunikasi, tempat berjumpa dengan teman-teman, salah satu media sosial, layanan dan bagian dari media masa. Responden (R3) dan 
responden (R4) mengatakan bahwa facebook merupakan salah satu media sosial. Menurut responden (R2) facebook adalah tempat bertemu dengan teman-teman yang berada di luar sekitar mereka. Responden memahamai pengertian facebook sesuai dengan pengertian yang mereka ungkapkan masing-masing.

\subsection{Pengertian Kehidupan Rohani}

Dari hasil penelitian di atas, para responden mengungkapkan tentang pengertiannya yang berhubungan dengan kehidupan rohani sesuai dengan definisi responden masing-masing. Jawaban para responden tentang pengertian kehidupan rohani bervariasi. Ada beberapa jawaban yang sama tentang pengertian kehidupan rohani dan ada juga yang berbeda antara satu responden dengan yang lainnya.

Delapan (8) responden masing-masing menyampaikan pengertiannya tentang kehidupan rohani. Pengertian yaang dikatakan oleh 8 (delapan) responden menyatakan bahwa masing-masing dari responden memahami arti dari kehidupan rohani sesuai dengan pemahaman yang mereka sampaikan. Mahasiswa STKIP Widya Yuwana mengatakan bahwa kehidupan rohani mengajarkan manusia untuk lebih beriman kepada Allah dengan cara berdoa. Berdoa merupakan suatu kebutuhan rohani yang harus dipenuhi untuk mendapatkan kehidupan rohani yang baik. Kehidupan rohani yang baik harus diperdalam dengan tindakan atau perbuatn yang baik. Tindakan dan perbuatan yang baik akan menghasilkan pikiran yang cerah, sehingga terang Roh Kudus akan hadir untuk menuntun kepada kehidupan rohani yang baik.

Kehidupan rohani yang sudah dipahami akan menjadi jalan bagi responden untuk menemukan kehidupan rohani yang baik. Kehidupan rohani yang baik harus disadari oleh responden untuk dapat menjadikannya lebih baik. Kehidupan rohani sebagai nafas bagi manusia untuk menemukan terang Allah yang sesungguhnya. Manusia diharuskan berdoa pada Allah demi memiliki iman yang kuat serta relasi yang baik dengan Allah sebagai pencipta. Allah adalah sumber hidup bagi manusia.

\subsection{Bentuk-bentuk Kehidupan Rohani}

Bentuk-bentuk kehidupan rohani tidak hanya dilaksanakan di dalam Gereja melainkan juga di luar Gereja. Kehidupan rohani di luar Gereja adalah doa pribadi, doa makan, doa tidur, doa belajar, meditasi dan doa untuk wujud tertentu yang langsung dibicarakan dengan Allah secara pribadi. Kehidupan rohani di luar Gereja mendukung manusia untuk menemukan Allah di dalam hidupnya. Para responden memahami bentukbentuk kehidupan rohani sesuai dengan kegiatan rohani yang telah dilaksanakan. Bentukbentuk kehidupan rohani yang dipahami oleh responden, bukan hanya sebuah teori melainkan juga praktek. Responden menjalankan bentuk-bentuk kehidupan rohani di dalam hidup sehari-hari.

Hasil penelitian mengatakan bahwa responden mengerti dan memahami bentukbentuk kehidupan rohani. Bentuk-bentuk kehidupan rohani sebagai bentuk kedalaman iman responden yang tetap dilaksanakan, namun dalam pelaksanaan masih ada beberapa waktu yang terlupakan. 


\subsection{Pengaruh Hidup Rohani bagi Kehidupan Pribadi}

Kehidupan rohani merupakan sesuatu yang harus selalu diimani. Kehidupan rohani sangat berpengaruh bagi kehidupan pribadi. Kehidupan pribadi akan terbentuk dengan baik melalui kehidupan rohani yang baik. Kehidupan rohani harus seimbang dengan kehidupan pribadi dengan demikian akan mendapatkan iman yang baik akan Allah. Kehidupan rohani yang baik membantu manusia dalam mengembangkan iman. Iman akan tumbuh melalui kehidupan rohani yang selalu dijaga dan dijalankan.

Kehidupan rohani berpengaruh bagi kehidupan pribadi. Kehidupan pribadi menjadi semakin beriman dewasa. Iman yang dewasa didapatkan melalui perbuatan kehidupan rohani yang selalu dijaga. Kehidupan pribadi yang seimbang dengan kehidupan rohani akan meningkatkan relasi yang baik dengan Tuhan dan memupuk relasi kasih dengan sesama manusia. Kehidupan rohani dan kehidupan pribadi harus selalu penuh iman akan Allah. Hidup yang beriman akan menjadikan kehidupan damai dan tenteram.

\subsection{Pengaruh Positif atau Negatif Penggunaan Facebook bagi Kehidupan Pribadi}

Facebook merupakan media yang terkenal pada zamannya. Facebook sebagai situs jejaring sosial (social networking) digunakan oleh banyak orang yang ada di dunia. Facebook memiliki dampak positif dan negatif bagi kehidupan rohani. Delapan (8) (responden) mengatakan bahwa facebook ada yang memiliki dampak positif, negatif dan seimbang antara keduanya bagi kehidupan rohani. Facebook merupakan media yang mengasyikkan. Facebook berdampak bagi kehidupan rohani karena dapat membuat seseorang lupa akan bentuk-bentuk kehidupan rohani yang harus dilaksanakan.

\subsection{Pengaruh Penggunaan Facebook bagi Kehidupan Pribadi}

Pengaruh negatif facebook membuat responden lupa untuk pergi ke Gereja untuk mengikuti perayaan ekaristi. Responden melupakan dunia dan cara baik dalam menggunakan facebook. Facebook memiliki dampak negatif terhadap kehidupan rohani responden, sehingga responden melupakan tugas dan kewajibannya sebagai mahasiswa STKIP Widya Yuwana yang belajar tentang teologi.

Responden menyampaikan pengaruh negatif dan positif penggunaan facebook bagi kehidupan rohani. Pengaruh penggunaan facebook secara negatif adalah facebook digunakan untuk menyebarkan berita atau informasi tidak sesuai dengan kenyataan. Facebook digunakan untuk menyampaikan perasaan yang kurang baik. Responden menyampaikan facebook selain memiliki pengaruh negatif juga memiliki pengaruh positif. Pengaruh positif yang disampaikan responden adalah dengan adanya facebook dapat mengetahui perkembangan zaman, mengetahui berita penting dan perkembangan negara.

\subsection{Cara Menggunakan Facebook untuk Mendukung Pertumbuhan Hidup Rohani}

Cara memperlakukan facebook untuk mendukung pertumbuhan iman adalah dengan memposting hal-hal yang positif misalnya kita bisa membuat sebuah renungan 
atau kata-kata motivasi yang berhubungan dengan kehidupan iman. Jadi mengekspos kata-kata atau gambar yang memberikan semangat.

Responden menyampaikan cara memperlakukan atau menggunakan facebook sebagai aplikasi untuk mendukung iman adalah dengan memposting atau mengirim hal positif yang berhubungan dengan kehidupan rohani. Kehidupan rohani yang dibagikan di facebook tentang kata-kata motivasi yang berhubungan dengan iman atau kehidupan rohani yang harus dilakukan dan dilaksanakan.

\section{KESIMPULAN}

Hasil penelitian ini menyimpulkan bahwa pengaruh penggunaan facebook bagi kehidupan rohani mahasiswa STKIP Widya Yuwana adalah menjadikan mahasiswa lupa waktu akan tugas dan kewajibannya untuk menjalankan kehidupan rohani yang sudah dijadwalkan dalam kehidupan sehari-hari. Penggunaan facebook berdampak bagi kehidupan rohani mahasiswa. Mahasiswa menjadi jauh dari Allah sebagai pencipta dan menyebabkan iman semakin berkurang sehingga kewajiban hidup rohani yang sudah diterima dan diajarkan menjadi hilang. Penggunaan facebook merupakan media yang lebih berdampak negatif bagi kehidupan rohani mahasiswa STKIP Widya Yuwana dalam menjalin relasi dengan Allah sebagai pencipta bagi manusia. Penggunaan facebook menjadikan relasi antara manusia dengan Allah semakin jauh dan menjadikan mahasiswa lupa waktu untuk menjalankan tugas dan kewajiban.

\section{DAFTAR PUSTAKA}

Agustinus, Hengky., 2015. Skripsi, Pemahaman Mahasiswa STKIP Widya Yuwana Madiun Tentang Pembinaan Kerohanian dan Pelaksanaannya.

Arief, Rudianto., M, 2011. Pemrograman Web Dinamis Menggunakan PHP dan MySQL, Yogyakarta: C. V ANDI OFFSET.

Arifin, Hasnul., 2009. Nongkrong Asyik di Internet Dengan Facebook, Jakarta: Buku Kita.

Budyapranata, AL., 1981. Membangun Keluarga Kristiani, Yogyakarta: Kanisius.

Cangara, Hafied (ed)., 1998. Pengantar Ilmu Komunikasi, Jakarta: PT. Grafindo Persada.

Darminta, Purwa W. J. S., 1985. Kamus Umum Bahasa Indonesia, Jakarta: Balai Pustaka.

Dokumen PKKI-VII., 2006. Katekese Umat Komunitas Basis Gerejawi Evaluasi Kurikulum PAK, Jakarta: Komisi Kateketik KWI.

Euvemia, Erma., 2018. Doa Bersama Dalam Keluarga Sebagai Sarana Pendidikan Iman Anak, Dalam Jurnal Pendidikan Agama Katolik Tahun 10 Tanggal 20 Oktober 2018 hal 27-30.

Heuken, A. dkk., 1975. Ensiklopedia Populer Tentang Gereja, Yogyakarta: Kanisius.

Heuken, A. dkk., 2005. Spiritualitas Kristiani: Pemekaran hidup rohani selama dua puluh abad, Jakarta. Yayasan Cipta Loka Caraka.

Hidya Tjahya, Thomas., 2011. Peziarahan Hati, Yogyakarta: Kanisius. 
Juna, Marsia., 2018. Makna dan Penghayatan Sakramen Ekaristi Bagi Calon Katekis, Dalam Jurnal Pendidikan Agama Katolik Tahun 10 Tanggal 20 Oktober 2018 hal 134-137.

Kindarto, Asdani., 2010. Efektif Blogging Dengan Aflikasi Facebook, Jakarta: Elex Media Komputindo.

Komisi Kateketik KWI., 2016. Katekese Di Era Digital, Yogyakarta: Kanisius.

KWI, 2012. Pedoman Pastoral Keluarga. Jakrta: Obor.

Mardiatmaja, 1982. Panggilan Hidup Manusia, Yogyakarta: Kanisius

Olson, Matthew H \& Hergenhahn, B.R., 2013. Pengantar Teori-Teori Kepribadian, Jakarta: Pustaka Pelajar.

Patriadi, Dicky., 2015. Skripsi, Pemahaman Mahasiswa STKIP Widya Yuwana Madiun Tentang Pembinaan Kerohanian Dan Pelaksanaannya.

Paulus II, Yohanes., 1993. Dokumen Konsili Vatikan II, Jakarta: Obor.

Poerwadarminta, 1976. Kamus Umum Bahasa Indonesia, Jakarta: Balai Pustaka.

Pradani, Angela Erma Setya., 2014. Skripsi, Perpepsi Mahasiswa Stkip Widya Yuwana Madiun Tentang Penggunaan Facebook Sebagai Media Pewartaan.

Saputra, Angga., 2010. Jurnal. Analisis Pengaruh Kepuasan, Kualitas, Dan Experiential Marketing Terhadap Word Of Mounth Situs Jejaring Sosial Facebook Pada Mahasiswa Fe Undip Semarang.

Supriyadi, Agustinus., 2018. Remaja Katolik, Gereja, dan Ekaristi, Dalam Jurnal Pendidikan Agama Katolik Tahun 10 Tanggal 20 Oktober 2018 hal 37-39. 